\title{
KEMAMPUAN KEPEMILIKAN INSTITUSIONAL MEMODERASI PENGARUH DIVERSITAS GENDER, KEBANGSAAN, PENGALAMAN DEWAN PADA LUAS INTELLECTUAL CAPITAL DISCLOSURE
}

\author{
Ida Ayu Ika Vedanti Pratiwi ${ }^{1}$ \\ I Dewa Nyoman Badera ${ }^{2}$ \\ I Ketut Budiartha ${ }^{3}$
}

${ }^{1}$ Fakultas Ekonomi dan Bisnis Universitas Udayana (Unud), Bali, Indonesia e-mail: vedantipratiwi@yahoo.com

${ }^{2}$ Fakultas Ekonomi dan Bisnis Universitas Udayana (Unud), Bali, Indonesia

${ }^{3}$ Fakultas Ekonomi dan Bisnis Universitas Udayana (Unud), Bali, Indonesia

\begin{abstract}
ABSTRAK
Penelitian ini bertujuan untuk memperoleh bukti empiris mengenai pengaruh diversitas gender, kebangsaan, dan pengalaman dewan direksi dan komisaris pada luas Intellectual Capital Disclosure (IC Disclosure), dengan kepemilikan institusional sebagai pemoderasi. Populasi penelitian berjumlah 440 perusahaan non keuangan dengan intensif modal intelektual yang terdaftar di BEI pada tahun 2012-2015. Sampel ditentukan melalui metode purposive sampling, yang pada akhirnya menghasilkan 78 perusahaan sampel. Data dianalisis menggunakan regresi linear berganda dan uji nilai selisih mutlak. Hasil penelitian menunjukkan bahwa diversitas gender berpengaruh negatif pada luas IC Disclosure, diversitas kebangsaan berpengaruh positif pada luas IC Disclosure, diversitas pengalaman tidak berpengaruh pada luas IC Disclosure, kepemilikan institusional memoderasi pengaruh diversitas gender dan kebangsaan pada luas IC Disclosure, serta kepemilikan institusional tidak memoderasi pengaruh diversitas pengalaman pada luas IC Disclosure.

Kata Kunci: diversitas gender, diversitas kebangsaan, diversitas pengalaman, IC Disclosure, kepemilikan institusional
\end{abstract}

\section{ABSTRACT}

This research aims to obtain empirical evidence about the effect of gender diversity, nationality, experience on the wideness of IC Disclosure with institutional ownership as moderating variable. The sample of this research amounted to 78 companies from 440 non financial companies with intensive intellectual capital that are registered at BEI during period year of 2012-2015. Data analysis technique used in this research is multiple regression analysis and absolute difference value test. The result of this research show that gender diversity has negative impact on the wideness of IC Disclosure, nationality diversity has positive impact on the wideness of IC Disclosure, experience diversity has not impact on the wideness of IC Disclosure, the institutional ownership is able to moderate the effect of gender and nationality diversity on the wideness of IC Disclosure, the institutional ownership is not able to moderate the effect of experience diversity on the wideness of IC Disclosure.

Keywords: gender diversity, nationality diversity, experience diversity, IC Disclosure, institutional ownership 
I.A Ika Vedanti Pratiwi, I Dewa Nym Badera, dan I Kt Budiartha. Kemampuan...

\section{PENDAHULUAN}

Fenomena yang terjadi dalam dunia bisnis menunjukkan bahwa manajemen memiliki motivasi untuk menyalahgunakan fleksibilitas yang ada dengan memodifikasi laporan keuangan, dimana laba suatu perusahaan kerap disajikan overstated, dengan tujuan untuk meningkatkan jumlah bonus yang diterima. Sebagai contoh yaitu PT. Kimia Farma dan Enron yang melakukan pencatatan laba secara berlebih, sehingga berdampak pada berkurangnya kepercayaan investor terhadap perusahaan yang tercermin dalam penurunan harga saham (Herwidayatmo, 2002; Foerthiono \& Sadjiarto, 2014).

Peningkatan kualitas transparansi informasi diyakini dapat menjadi alternatif kebijakan yang ditempuh perusahaan untuk mengembalikan kepercayaan investor, sebab menurut Purwanto dan Wikartika (2014) pengungkapan informasi yang memadai akan sejalan dengan peningkatan kepercayaan investor. Salah satu jenis pengungkapan yang patut mendapat perhatian perusahaan ialah Intellectual Capital Disclosure (IC Disclosure).

Pentingnya IC Disclosure dalam dunia bisnis dapat dilihat dari beragam manfaat yang dihadirkannya, yaitu: 1) IC Disclosure dapat meningkatkan nilai perusahaan (Devi, 2016), 2) IC Diclosure mampu menjembatani asimetri informasi yang kerap timbul diantara nilai pasar dan nilai buku melalui kemampuannya dalam menjelaskan unexplained value (Purnomosidhi, 2006), 3) bagi investor, informasi modal intelektual merupakan salah satu dasar untuk menilai kualitas perusahaan, sehingga pada akhirnya mampu meraih keuntungan dalam bentuk abnormal return (Sir dkk., 2010). 
Namun Purnomosidhi (2006) menyebutkan bahwa masih terdapat beberapa perusahaan di Indonesia yang belum memahami informasi modal intelektual secara menyeluruh, sehingga pelaporan dan pengungkapannya cenderung kurang maksimal diterapkan. Sebagai upaya untuk mempermudah perusahaan memahami intellectual capital, para praktisi akuntansi Indonesia telah mencoba mengulasnya dalam PSAK No. 19 revisi tahun 2015. Aturan tersebut seharusnya mampu memotivasi perusahaan agar meningkatkan keterbukaan atas informasi modal intelektual, namun mengingat informasi ini tergolong dalam intangible asset, maka sulit bagi perusahaan untuk menyajikan dalam bentuk rekening dan melaporkannya pada laporan keuangan (Devi, 2016). Oleh sebab itu, alternatif yang ditawarkan untuk memfasilitasi kebutuhan informasi pelaku pasar modal atas intellectual capital ialah meningkatkan kualitas transparansi informasi dengan memperluas Intellectual Capital Disclosure secara sukarela (Sir dkk., 2010).

Diversitas diyakini akan menciptakan gaya kognitif yang bervariasi, sehingga mampu memperkaya alternatif kebijakan, guna menunjang kualitas suatu keputusan (Williams \& O’Reilly, 1998). Penelitian ini merujuk penelitian sebelumnya yang dilakukan Rasmini et al (2014) yaitu mengkaji pengaruh diversitas demografi seperti diversitas gender dan kebangsaan, serta diversitas kognitif seperti diversitas latar belakang pendidikan pada luas pengungkapan modal intelektual. Kemudian sebagai unsur pembeda, diversitas kognitif yang digunakan pada penelitian ini berupa diversitas pengalaman, sesuai saran penelitian yang diungkapkan Rasmini et al (2014). 
I.A Ika Vedanti Pratiwi, I Dewa Nym Badera, dan I Kt Budiartha. Kemampuan...

Diversitas gender merupakan salah satu human aspect yang mampu menarik perhatian pada akademisi untuk melakukan kajian lebih mandalam. Isu ini mendapat perhatian sejak adanya fenonema bahwa wanita mulai mendapat kesempatan untuk menjadi bagian dari jajaran dewan perusahaan, walaupun pada awalnya beberapa pihak meragukan kemampuan wanita dalam memimpin dan kerap menempatkannya pada posisi pendukung (menomor duakan) dari laki-laki pada saat pengambilan keputusan. Namun seiring perkembangan zaman, kesetaraan gender mulai digaungkan, yang ditandai dengan adanya Intruksi Presiden Republik Indonesia Nomor 9 Tahun 2000 Tentang Pengarustamaan Gender Dalam Pembangunan Nasional. Bahkan penelitian Rasmini et al (2014) menyebutkan bahwa keberadaan dewan direksi dan komisaris wanita berpengaruh pada luas voluntary disclosure, khususnya IC Disclosure yang dilakukan suatu perusahaan. Disisi berbeda, penelitan Oba et al (2013), dan Sartawi et al (2014) memperoleh hasil berlawanan.

Susunan dewan direksi dan komisaris dalam suatu perusahaan tidak hanya memperlihatkan isu diversitas gender, dewasa ini hadirnya era globalisasi memberikan peluang masuknya aliran modal dari berbagai negara ke perusahaanperusahaan di Indonesia yang secara langsung membuka jalan bagi warga negara asing untuk bekerja di Indonesia. Menurut data yang dimiliki oleh Kemenkumham, jumlah tenaga asing di Indonesia hingga tahun 2015 meningkat menjadi 79.664 orang (Kompas, 20 Juli 2016).

Diversitas kebangsaan diharapkan dapat menghadirkan warna baru dalam susunan dewan direksi dan komisaris, baik dalam sudut pandang, budaya 
kehidupan, opini, keahlian, dan tingkat profesionalitas yang berbeda, sehingga akan memperkaya pengetahuan bisnis maupun alternatif strategi pemecahan masalah (Rasmini et al., 2014). Bahkan beberapa peneliti sebelumnya menyebutkan bahwa keberadaan dewan berkebangsaan asing memberi dampak positif pada peningkatan kualitas keterbukaan informasi sukarela, seperti IC Disclosure (Oba et al., 2013 \& Rasmini et al., 2014). Di sisi berbeda, penelitian Baroko dan Brown (2008) menunjukkan hasil berlawanan, yaitu struktur dewan dengan kebangsaan yang heterogen tidak berpengaruh pada luas voluntary disclosure.

Perbedaan karakteristik dewan juga dapat dilihat dari diversitas kognitif yang dimiliki, seperti diversitas pengalaman, yang dalam hal ini difokuskan pada pengalaman kerja dewan direksi dan komisaris di satu perusahaan (Li et al., 2013). Merujuk penelitian Li et al (2013), Oyieke (2014) dan Sulaeman (2014), pengalaman kerja diukur melalui masa jabatan (board of tenure) dengan pertimbangan yaitu semakin panjang masa jabatan akan menghadirkan pengalaman kerja beragam, termasuk pula pengalaman dalam menghadapi dan memahami lingkungan bisnis perusahaan, sehingga dewan dapat menetapkan strategi dengan lebih baik guna menopang keberlangsungan usaha. Hasil penelitian Gouiaa dan Zeghal (2015) menyebutkan bahwa dewan direksi dan komisaris dengan masa jabatan yang panjang berpengaruh positif pada peningkatan luas voluntary disclosure, namun hasil penelitian berlawanan masih ditemukan oleh Soheilyfar et al (2014). 
I.A Ika Vedanti Pratiwi, I Dewa Nym Badera, dan I Kt Budiartha. Kemampuan...

Adanya ketidakseragaman atas hasil-hasil penelitian sebelumnya memotivasi peneliti untuk mengajukan kepemilikan institusional sebagai variabel moderasi, dengan dasar pemikiran yaitu kepemilikan institusional merupakan cerminan pengawasan dari pemegang saham mayoritas perusahaan. Dimana melalui power yang ada, investor institusi diyakini mampu menjadi agen pengawas yang efektif dalam mengontrol dan memastikan bahwa kebutuhan informasi para stakeholder telah terakomodir dengan baik (Smith, 1996).

Penelitian ini dilakukan guna mendapat bukti empiris mengenai: 1) pengaruh diversitas gender dari dewan direksi dan komisaris pada luas IC Disclosure, 2) pengaruh diversitas kebangsaan dari dewan direksi dan komisaris pada luas IC Disclosure, 3) pengaruh diversitas pengalaman dari dewan direksi dan komisaris pada luas IC Disclosure, 4) kemampuan kepemilikan institusional memoderasi pengaruh diversitas gender dari dewan direksi dan komisaris pada luas IC Disclosure, 5) kemampuan kepemilikan institusional memoderasi pengaruh diversitas kebangsaan dari dewan direksi dan komisaris pada luas $I C$ Disclosure, 6) kemampuan kepemilikan institusional memoderasi pengaruh diversitas pengalaman dari dewan direksi dan komisaris pada luas IC Disclosure.

Manfaat teoritis penelitian ini ialah memberi kontribusi terhadap pengembangan ilmu pengetahuan, khususnya yang berkaitan dengan pengaruh diversitas gender, kebangsaan, dan pengalaman dewan direksi dan komisaris pada luas IC Disclosure, serta kemampuan kepemilikan institusional dalam memoderasi pengaruh tersebut. Selain itu, penelitian ini berupaya memberi bahan pertimbangan kepada perusahaan agar memperhatikan keberagaman dewan 
(board of diversity) ketika menetapkan strategi pemilihan anggota dewan direksi dan komisaris, sehingga pada akhirnya mampu mendorong peningkatan luas pengungkapan informasi sukarela khususnya IC Disclosure.

Teori keagenan menggambarkan adanya kontrak kerjasama diantara seorang lebih prinsipal dengan agen, dimana prinsipal menyakini kualitas dan kompetensi agen, sehingga memantapkan niatnya untuk mendelegasikan wewenang terkait pengelolaan dan pengambilan keputusan-keputusan penting perusahaan kepada agen tersebut (Jensen \& Meckling, 1976).

Fenomena yang terjadi dalam kontrak keagenan menunjukkan bahwa agen tidak selalu bertindak untuk kepentingan terbaik para pemegang saham, dimana adanya asimetri informasi memberi peluang kepada agen sebagai pemilik mayoritas informasi perusahaan untuk menetapkan kebijakan yang cenderung merugikan pemegang saham dan mensejahterakan dirinya sendiri (Jensen \& Meckling, 1976). Pada kondisi inilah penerapan asas good corporate governance menjadi salah satu prioritas perusahaan, sehingga tercipta pola pengendalian yang berkualitas dalam mencegah kemungkinan manajemen bersikap opportunistik. Teori keagenan juga menekankan keterkaitan antara good corporate governance dengan luas pengungkapan informasi, dimana untuk meminimalisasi konflik, perusahaan perlu memperkecil asimetri informasi yang ada dengan memaksimalkan penerapan transparansi informasi melalui peningkatan luas voluntary disclosure (Rasmini et al., 2014).

Kartikarini dan Mutmainah (2013) mengungkapkan bahwa perilaku disclosure suatu perusahaan ditentukan oleh perilaku maupun karakteristik para 
I.A Ika Vedanti Pratiwi, I Dewa Nym Badera, dan I Kt Budiartha. Kemampuan...

pakar penyusunnya yaitu dewan direksi dan komisaris. Hal ini sesuai dengan teori ketergantungan sumber daya yang menjelaskan bahwa dewan direksi dan komisaris merupakan jembatan penghubung antara perusahaan dengan lingkungan, yang diharapkan mampu meminimalisasi ketidakpastian lingkungan dan menyediakan segenap informasi maupun sumber daya yang diperlukan (Rahindayati dkk., 2015). Pada konteks ini, dewan akan menetapkan kebijakan untuk memperluas pengungkapan informasi modal intelektual agar dapat meyakinkan penyedia sumber daya untuk mendistribusikan sejumlah sumber daya yang dimiliki kepada perusahaan. Dewan direksi dan komisaris juga berperan sebagai pengendali internal (control role) yang berwenang untuk mengontrol perilaku mementingkan diri sendiri manajemen, sehingga kebutuhan pemegang saham dapat terakomodir dengan baik, termasuk diantaranya kebutuhan atas sejumlah informasi modal intelektual (Rasmini et al., 2014).

Pada umumnya, modal intelektual menjadi kunci keunggulan perusahaan karena mencerminkan sekumpulan aset tidak berwujud yang mampu mendukung kelancaran operasional usaha. Peneliti terdahulu, seperti CIMA (2014) mendefinisikan modal intelektual sebagai pengetahuan, pengalaman, teknologi, keterampilan profesional, dan hubungan perusahaan dengan konsumennya (pelanggan) yang apabila diaplikasikan dengan baik dapat menciptakan keunggulan kompetitif bagi perusahaan. Hingga kini, penyebarluasan informasi mengenai modal intelektual atau yang dikenal dengan Intellectual Capital Disclosure (IC Disclosure) masih bersifat sukarela, sehingga kesadaran 
perusahaan untuk meningkatkan keterbukaan informasi demi memenuhi kebutuhan pelaku pasar modal menjadi hal penting untuk diperhatikan.

IC Disclosure didefinisikan sebagai sebuah laporan yang dibuat oleh manajemen, dengan tujuan untuk mengukur aset tidak berwujud perusahaan dan memenuhi kebutuhan informasi modal intelektual para penggunanya, baik dari aspek human capital, structural capital, maupun customer capital (Devi, 2016). Peningkatan luas informasi modal intelektual ini dipengaruhi oleh beragamnya karakteristik para pakar penyusunnya (dewan direksi dan komisaris), yang dalam hal ini dikenal dengan istilah board of diversity.

Salah satu jenis diversitas yang umum ditemukan dalam perusahaan adalah diversitas gender. Diversitas ini menekankan adanya dewan direksi dan komisaris wanita dalam perusahaan. Menurut Robbins dan Judge (2008: 206) serta Baroroh (2013) dewan wanita memiliki pembawaan gemar melakukan analisis, dimana strategi yang ditetapkannya diyakini telah berdasar pada pertimbangan yang seksama dan mampu mengantarkan kinerja ke arah yang lebih baik, sehingga pada akhirnya akan mendorong keterbukaan informasi modal intelektual (Rasmini et al., 2014). Namun ketika perusahaan telah mencapai taraf kesuksesan tertentu, dewan direksi dan komisaris wanita kerap menunjukkan kehati-hatiannya dalam pengambilan keputusan dan cenderung membatasi pengungkapan beberapa informasi penting guna meminimalisasi potensi kerugian (Francis et al., 2014). Adapun rumusan hipotesis ialah

$\mathrm{H}_{1}$ : diversitas gender berpengaruh positif pada luas intellectual capital disclosure 
I.A Ika Vedanti Pratiwi, I Dewa Nym Badera, dan I Kt Budiartha. Kemampuan...

Dewasa ini, struktur dewan dalam perusahaan juga kerap menunjukkan adanya diversitas kebangsaan, yang ditandai dengan keberadaan dewan direksi dan komisaris berkebangsaan heterogen. Dewan berkebangsaan asing diharapkan mampu menghadirkan iklim positif dalam proses pengelolaan perusahaan melalui upaya untuk memaksimalkan pertukaran dan keterbukaan informasi yang umumnya sejalan dengan peningkatan luas pengungkapkan informasi sukarela (Widodo dan Widagdo, 2015), termasuk informasi modal intelektual. Berdasarkan pemaparan tersebut, adapun hipotesis yang dirumuskan adalah

$\mathrm{H}_{2}$ : diversitas kebangsaan berpengaruh positif pada luas intellectual capital disclosure

Keberagaman karakteristik dewan direksi dan komisaris juga dapat dilihat dari diversitas pengalaman, khususnya pengalaman kerja masing-masing dewan di suatu perusahaan. Pada penelitian ini, pengalaman kerja diproksikan dengan masa jabatan karena menggambarkan adanya pengalaman kerja beragam, kompetensi, dan pengetahuan yang dimiliki dalam mengelola dan mengawasi proses operasional perusahaan (Li et al., 2013), sehingga berpotensi untuk meningkatkan kinerja dan mendorong pengungkapan informasi (Rasmini et al., 2014). Disisi berbeda, Finkelstein dan Hambrick (1990) mengungkapkan bahwa dewan dengan masa jabatan dewan yang panjang cenderung mempertahankan status quo yang ada dan enggan untuk mengadopsi strategi-strategi baru, seperti contohnya mengoptimalkan pemanfaatan maupun pengungkapan informasi modal intelektual. Berdasarkan pemaparan tersebut, adapun hipotesis yang dirumuskan ialah 
$\mathrm{H}_{3}$ : diversitas pengalaman berpengaruh positif pada luas intellectual capital disclosure

Teori kontijensi umumnya menekankan bahwa variabel moderasi dapat dimasukkan dalam suatu model penelitian ketika terdapat ketidakonsistenan atas hasil-hasil penelitian terdahulu (Gonvindarajan, 1986 dalam Poerwati, 2001). Adapun variabel moderasi yang digunakan pada penelitian ini berupa kepemilikan institusional.

Smith (1996) mengungkapkan bahwa keberadaan investor institusi yang tercermin dalam kepemilikan saham institusional diharapkan mampu mengawasi dan memastikan bahwa perusahaan telah dijalankan berdasar pada sistem tata kelola yang mempuni, termasuk di dalamnya mendorong dewan direksi dan komisaris wanita agar lebih meningkatkan transparansi informasi. Namun ketika dihadapkan dengan strategi bisnis, investor institusi sebagai pemegang saham mayoritas cenderung akan melindungi sejumlah besar kepemilikan sahamnya dengan menahan beberapa informasi penting perusahaan, guna menghindari dimanfaatkannya informasi tersebut oleh pesaing (Nuryaman, 2009). Berdasarkan pemaparan tersebut, adapun hipotesis yang dapat dirumuskan adalah

$\mathrm{H}_{4}$ : kepemilikan institusional memperkuat pengaruh diversitas gender pada luas intellectual capital disclosure.

Interaksi yang terjadi antara diversitas kebangsaan dan kepemilikan institusional diharapkan mampu meningkatkan luas IC Disclosure yang diterapkan suatu perusahaan. Investor institusi sebagai pemegang saham mayoritas akan mendukung keputusan dewan asing untuk lebih terbuka atas 
I.A Ika Vedanti Pratiwi, I Dewa Nym Badera, dan I Kt Budiartha. Kemampuan...

informasi modal intelektual guna meningkatkan kredibilitas dan nilai perusahaan yang tercermin dari fluktuasi harga saham (Devi, 2016). Tingginya kepemilikan saham berbanding lurus dengan cashflow yang akan diterima oleh pemegang saham, yang mana apabila harga saham naik, maka investor institusi sebagai pemegang saham mayoritas yang paling banyak merasakan manfaatnya (Nuryaman, 2009). Berdasarkan pemaparan tersebut adapun hipotesis yang dirumuskan adalah

$\mathrm{H}_{5}$ : kepemilikan institusional memperkuat pengaruh diversitas kebangsaan pada luas intellectual capital disclosure.

Pada umumnya ketika suatu perusahaan dikelola oleh dewan direksi dan komisaris dengan pengalaman kerja mempuni dan memiliki reputasi yang baik, maka akan melahirkan kepercayaan dari pemegang saham bahwa proses operasional perusahaan senantiasa berpedoman pada standar/prinsip yang berlaku. Namun kepercayaan ini juga menyebabkan berkurangnya motivasi pemegang saham untuk mengawasi pengelolaan perusahaan (Jones, 2014). Berdasarkan pemaparan tersebut, adapun hipotesis yang dapat dirumuskan adalah

$\mathrm{H}_{6}$ : kepemilikan institusional memperkuat pengaruh diversitas pengalaman pada luas intellectual capital disclosure.

\section{METODE PENELITIAN}

Ruang lingkup penelitian terbatas pada pengaruh diversitas gender, kebangsaan, dan pengalaman dewan direksi dan komisaris pada luas intellectual capital disclosure, serta mengkaji pengaruh moderasi dari kepemilikan 
institusional terhadap hubungan antara diversitas gender, kebangsaan, dan pengalaman dewan pada luas intellectual capital disclosure.

Populasi penelitian berupa perusahaan-perusahaan non keuangan dengan intensif modal intelektual di BEI. Perusahaan-perusahaan non keuangan dengan intensif modal intelektual didefinisikan sebagai sekumpulan perusahaan yang memiliki value added besar karena kemampuannya dalam memanfaatkan teknologi dan pengetahuan yang dimiliki (Abdiani dan Nugrahanti, 2014). Pertimbangan menggunakan perusahan dari sektor non keuangan adalah pertama, menurut Global Industries Classification (GICS), $67 \%$ perusahaan yang memiliki modal intelektual intensif didominasi oleh perusahaan sektor non keuangan (Abdiani dan Nugrahanti, 2014), kedua yaitu sebagai upaya untuk meminimalisasi kesalahan penafsiran pada saat mengklasifikasian item-item intellectual capital khususnya dari segi customer capital. Adapun populasi dalam penelitian ini terbagi dalam sepuluh sektor yaitu 1) Electronics, 2) Telecommunication, 3) Computer and Services, 4) Advertising, Printing, and Media, 5) Automotive and Components, 6) Pharmaceuticals, 7) Health Care, 8) Property and Real Estate, 9) Building Constuction, dan 10) Cable.

Sampel ditentukan dengan metode purposive sampling, melalui beberapa kriteria, yaitu.

1) Perusahaan-perusahaan non keuangan dengan intensif modal intelektual yang terdaftar di Bursa Efek Indonesia dan menerbitkan laporan tahunan pada tahun 2012, 2013, 2014, dan 2015. 
I.A Ika Vedanti Pratiwi, I Dewa Nym Badera, dan I Kt Budiartha. Kemampuan...

2) Perusahaan yang mendeskripsikan karateristik dewan direksi maupun komisarisnya, seperti dalam hal jenis kelamin, kewarganegaraan, maupun lamanya masa jabatan.

3) Perusahaan yang mempublikasikan jumlah saham institusional dan jumlah saham beredar.

Proses pemilihan sampel akan dijabarkkan pada Tabel 1.

Tabel 1.

Proses Pemilihan Sampel

\begin{tabular}{|c|c|c|c|c|c|c|}
\hline \multirow{2}{*}{ No } & \multirow{2}{*}{ Kriteria } & \multicolumn{4}{|c|}{ Tahun Amatan } & \multirow{2}{*}{ Jumlah } \\
\hline & & 2012 & 2013 & 2014 & 2015 & \\
\hline 1 & $\begin{array}{l}\text { Perusahaan-perusahaan non keuangan dengan } \\
\text { intensif modal intelektual yang terdaftar di } \\
\text { BEI pada tahun 2012-2015 }\end{array}$ & 119 & 105 & 107 & 109 & 440 \\
\hline 2 & $\begin{array}{l}\text { Perusahaan-perusahaan non keuangan dengan } \\
\text { intensif modal intelektual yang tidak } \\
\text { mempublikasikan laporan tahunan pada } \\
\text { periode amatan karena merger, delisting, atau } \\
\text { laporan tahunan tidak tersaji pada website BEI } \\
\text { dan website masing-masing perusahaan }\end{array}$ & (6) & (1) & (2) & (7) & (16) \\
\hline 3 & $\begin{array}{l}\text { Perusahaan yang tidak mendeskripsikan } \\
\text { karakteristik dewan direksi dan komisaris } \\
\text { secara lengkap, baik dalam hal jenis kelamin, } \\
\text { kewarganegaraan, dan masa jabatan }\end{array}$ & (92) & (80) & (80) & (75) & (327) \\
\hline 4 & $\begin{array}{l}\text { Perusahaan yang tidak mempublikasikan } \\
\text { jumlah kepemilikan saham institusional dan } \\
\text { jumlah saham beredar }\end{array}$ & (5) & (3) & (2) & (3) & (13) \\
\hline \multirow[t]{2}{*}{5} & Data Outlier & (0) & (1) & (1) & (4) & (6) \\
\hline & Jumlah Sampel Akhir & 16 & 20 & 22 & 20 & 78 \\
\hline
\end{tabular}

Sumber: Data yang diolah, 2016

Merujuk pada Tabel 1, maka dapat dijelaskan bahwa terdapat 78 perusahaan non keuangan dengan intensif modal intelektual yang layak digunakan sebagai sampel penelitian.

Penelitian ini menggunakan beberapa variabel, yang akan diklasifikasikan ke dalam tiga jenis variabel, yaitu sebagai berikut. 
1) Variabel terikat (dependen) berupa luas Intellectual Capital Disclosure (IC Disclosure). IC Disclosure merupakan sebuah laporan yang disajikan untuk menyampaikan informasi intellectual capital kepada para stakeholder (Devi, 2016). Pengukuran IC Disclosure menggunakan IC Disclosure Index, sesuai dengan penelitian Devi (2016).

2) Variabel bebas (independen) terdiri atas tiga jenis variabel, yaitu: a) diversitas gender menggambarkan bahwa dalam susunan dewan direksi dan komisaris terdapat dewan berjenis kelamin laki-laki dan wanita lengkap dengan karakteristiknya masing-masing. Proksi diversitas gender ialah persentase dewan direksi dan komisaris wanita dalam perusahaan (Oba et al., 2013 \& Rahindayati dkk., 2015). b) diversitas kebangsaan menggambarkan persebaran dewan direksi dan komisaris dari segi kewarganegaraan yang ditandai dengan adanya dewan berkebangsaan asing. Diversitas kebangsaan diproksikan dengan persentase jumlah dewan berkebangsaan asing dalam perusahaan (Winato \& Supatmi, 2016). c) diversitas pengalaman dalam penelitian ini difokuskan pada pengalaman kerja dewan direksi dan komisaris di suatu perusahaan. Pengalaman kerja merupakan proses bertambahnya pengetahuan maupun keterampilan individu tentang pekerjaannya (Sulaeman, 2014). Diversitas pengalaman kerja diukur dari rata-rata masa jabatan dewan direksi dan komisaris dalam perusahaan (Kahle \& Lewellyn, 2011).

3) Variabel moderasi dalam penelitian ini ialah kepemilikan saham institusional yang didefinisikan sebagai proporsi saham akhir tahun dari 
I.A Ika Vedanti Pratiwi, I Dewa Nym Badera, dan I Kt Budiartha. Kemampuan...

investor institusi yaitu perusahaan swasta nasional, perusahaan efek, LSM, lembaga perbankan, dan lainnya (Febriana \& Nugrahanti, 2013). Adapun proksi dari kepemilikan institusional ialah persentase kepemilikan saham institusional perusahaan (Febriana \& Nugrahanti, 2013).

Data dikumpulkan dengan metode dokumentasi yaitu mengunduh dokumen IDX Statistics maupun annual report dari www.idx.co.id dan website resmi perusahaan. Sedangkan untuk menganalisis IC Disclosure menggunakan metode pengumpulan data berupa content analysis. Data yang telah terkumpul akan dianalisis melalui teknik regresi linear berganda (untuk menguji hipotesis 1-3) dan uji nilai selisih mutlak (untuk menguji hipotesis 4-6). Namun sebelum analisis tersebut dilakukan, perlu kiranya menerapkan uji asumsi klasik, diantaranya ialah pengujian heteoskedastisitas, autokorelasi, multikolonieritas, dan normalitas data. Proses pengolahan data menjadi lebih maksimal melalui pengaplikasian program SPSS versi 22.

Persamaan regresi yang dapat diajukan untuk menguji hipotesis penelitian adalah

a) Persamaan regresi untuk hipotesis 1 hingga hipotesis 3

$\mathrm{Y}=\alpha+\beta_{1} \mathrm{X}_{1}+\beta_{2} \mathrm{X}_{2}+\beta_{3} \mathrm{X}_{3}+\mathrm{e}$

b) Persamaan regresi untuk hipotesis 4 hingga hipotesis 6

$Y=\alpha+\beta_{1} X_{1}+\beta_{2} X_{2}+\beta_{3} X_{3}+\beta_{4} X_{4}+\beta_{5}\left|X_{1} \cdot X_{4}\right|+\beta_{6}\left|X_{2} \cdot X_{4}\right|+$ $\beta_{7}\left|X_{3} \cdot X_{4}\right|+\mathrm{e}$

Keterangan:

$\mathrm{Y}=$ IC Disclosure Index

$\mathrm{X}_{1} \quad=$ diversitas gender

$\mathrm{X}_{2} \quad=$ diversitas kebangsaan

$\mathrm{X}_{3} \quad=$ diversitas pengalaman

$\mathrm{X}_{4}=$ kepemilikan institusional 


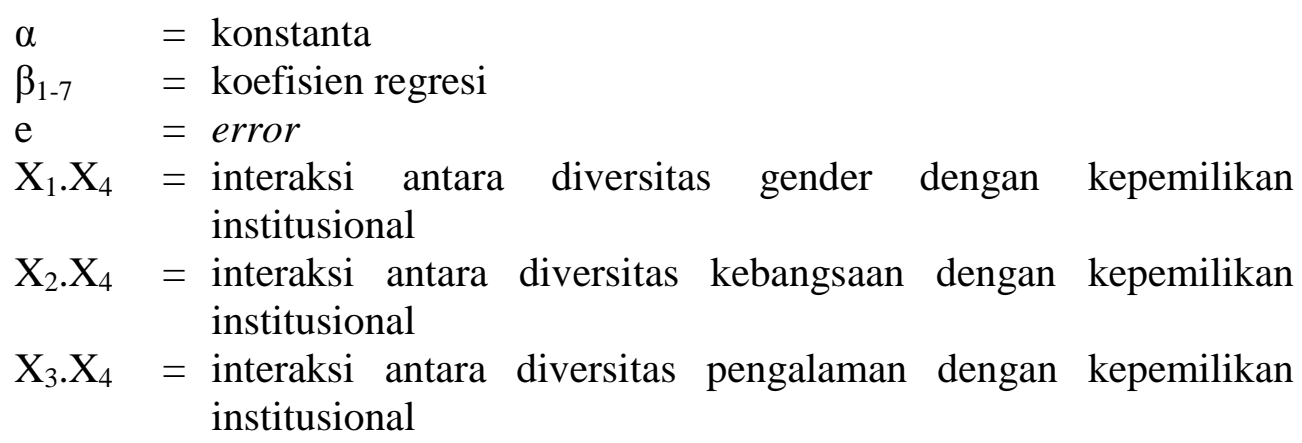

Ghozali (2016: 95) menekankan bahwa Goodness of Fit perlu diaplikasikan untuk menilai sejauh mana model regresi mampu menafsirkan nilai actual dengan tepat, melalui beberapa jenis pengujian, yaitu nilai koefisien determinasi $\left(\mathrm{R}^{2}\right)$, nilai kelayakan model (uji statistik F), dan nilai signifikansi parameter individual (uji statistik t).

\section{HASIL DAN PEMBAHASAN}

\section{Analisis Deskriptif}

Analisis deskriptif disajikan untuk menggambarkan karakter dari seluruh variabel, seperti diversitas gender, diversitas kebangsaan, diversitas pengalaman yang dilihat dari masa jabatan, kepemilikan institusional, dan IC Disclosure Index. Hasil statistik deskriptif akan dijabarkan pada Tabel 2

Tabel 2.

Hasil Uji Statistik Deskriptif

\begin{tabular}{lcrrrr}
\hline & N & Minimum & Maximum & Mean & $\begin{array}{c}\text { Std. } \\
\text { Deviation }\end{array}$ \\
\hline IC Disclosure Index $(\mathrm{y})$ & 78 & 0,36 & 0,52 & 0,43 & 0,04 \\
Diversitas Gender $\left(\mathrm{X}_{1}\right)$ & 78 & 0,08 & 0,38 & 0,17 & 0,07 \\
Diversitas Kebangsaan $\left(\mathrm{X}_{2}\right)$ & 78 & 0,07 & 0,75 & 0,23 & 0,17 \\
Diversitas Pengalaman $\left(\mathrm{X}_{3}\right)$ & 78 & 0,09 & 9,85 & 4,08 & 1,86 \\
Kepemilikan & 78 & 0,08 & 0,94 & 0,61 & 0,20 \\
\hline
\end{tabular}


I.A Ika Vedanti Pratiwi, I Dewa Nym Badera, dan I Kt Budiartha. Kemampuan...

Institusional $\left(\mathrm{X}_{4}\right)$

Sumber: Data yang diolah, 2016

Tabel 2 menunjukkan nilai $\mathrm{N}$ sebesar 78 yang berarti jumlah sampel penelitian sebanyak 78 perusahaan. Nilai minimum, maksimum, maupun mean dari diversitas gender dan kebangsaan yang lebih tinggi dari 0,00 dan lebih rendah dari 1,00 menjelaskan bahwa pada seluruh sampel penelitian telah terjadi diversitas gender dan kebangsaan. Variabel diversitas pengalaman memiliki nilai minimum sebesar 0,09 berarti bahwa terdapat dewan dengan masa jabatan kurang dari 1 tahun, sedangkan angka mean sebanyak 4,08 menunjukkan bahwa rata-rata dewan telah menjabat sebagai dewan direksi dan komisaris selama 4 tahun. Variabel kepemilikan institusional memiliki nilai minimum sebanyak 0,08 berarti terdapat perusahaan memiliki persentase kepemilikan saham institusi terendah sebanyak $8 \%$, hal ini menunjukkan bahwa perusahaan tersebut tersebut cenderung didominasi oleh kepemilikan saham keluarga. Sedangkan nilai mean sebanyak 0,610 menjelaskan dari 78 sampel perusahaan, rata-rata memiliki saham institusi sejumlah 61\%. Nilai mean dari IC Disclosure Index sebesar 0,435 menunjukkan bahwa perusahaan sampel mempublikasikan informasi modal intelektual rata-rata sebanyak 35 dari 81 item pengungkapan.

\section{Uji Asumsi Klasik}

Uji normalitas melalui Kolmogorov Smirnov Test memperoleh nilai Asymp. Sig (2-tailed) $>0,05$, sehingga data terdistribusi normal. Begitupula dengan uji Glejser menekankan bahwa tingkat signifikansi yang diperoleh di atas $\alpha=0,05$. Oleh sebab itu model regresi bebas dari heteroskedastisitas. Hasil pengujian 
multikolonieritas memperoleh nilai tolerance melebihi 0,10 , begitupula nilai VIF lebih rendah dari 10, sehingga tidak terdapat multikolonieritas antar variabel independen. Hasil pengujian autokorelasi melalui uji Durbin-Watson menunjukkan nilai dw jatuh pada daerah bebas autokorelasi $(\mathrm{dw}>\mathrm{du}$ dan $\mathrm{dw}<$ 4-du), sehingga persamaan regresi terbebas dari gejala autokorelasi.

\section{Hasil Regresi Linear Berganda}

Hasil pengujian hipotesis 1 hingga hipotesis 3 dengan menggunakan analisis regresi linear berganda akan disajikan pada Tabel 3, sebagai berikut.

Tabel. 3

Hasil Regresi Linear Berganda

\begin{tabular}{ccccrr}
\hline Model & \multicolumn{2}{c}{$\begin{array}{c}\text { Unstandardized } \\
\text { Coefficients } \\
\text { Std. Error }\end{array}$} & $\begin{array}{c}\text { Standardized } \\
\text { Coefficients } \\
\text { Beta }\end{array}$ & $\mathrm{t}$ & Prob. \\
\hline $\mathrm{C}$ & 0,456 & 0,015 & & 31,101 & 0,000 \\
$\mathrm{X}_{1^{*}}$ & $-0,238$ & 0,051 & $-0,456$ & $-4,688$ & $* 0,000$ \\
$\mathrm{X}_{2 *}$ & 0,066 & 0,023 & 0,295 & 2,913 & $* 0,005$ \\
$\mathrm{X}_{3}$ & 0,001 & 0,002 & 0,054 & 0,537 & 0,593 \\
Uji F & & & 10,572 & & \\
Sig. F & & 0,000 & & \\
Adjusted $R$ Square & & & 0,272 & & \\
\hline
\end{tabular}

Sumber : Data yang diolah, 2016

Keterangan : $*$ berpengaruh signifikan pada tingkat signifikansi $5 \%$

Berdasarkan Tabel 3 di atas, maka dirumuskan persamaan regesi sebagai berikut.

$\mathrm{Y}=0,456-0,238 \mathrm{X}_{1}+0,066 \mathrm{X}_{2}+0,001 \mathrm{X}_{3}+\mathrm{e}$

Tabel 3 menunjukkan nilai $\mathrm{F}_{\text {hitung }}$ sebesar 10,572 dengan tingkat signifikansi sebesar $0,000<\alpha=0,05$. Hal tersebut menjelaskan bahwa seluruh variabel bebas mempengaruhi perubahan variabel terikatnya, dimana model yang digunakan 
I.A Ika Vedanti Pratiwi, I Dewa Nym Badera, dan I Kt Budiartha. Kemampuan...

dinyatakan layak (fit). Nilai Adjusted $R^{2}$ sebesar 0,272 atau 27,2 persen menunjukkan bahwa 27,2 persen variabilitas dari luas IC Dislosure dipengaruhi oleh diversitas gender, kebangsaan, dan pengalaman.

Tabel 3 juga menjelaskan bahwa variabel diversitas gender $\left(\mathrm{X}_{1}\right)$ memiliki nilai $p$-value sebesar $0,000 / 2=0,000$ (uji satu sisi) lebih rendah dari $\alpha=0,05$ dengan nilai koefisien $\beta=-0,238$. Hal ini berarti diversitas gender berpengaruh negatif pada luas IC Disclosure, sehingga $\mathrm{H}_{1}$ diterima. Begitupula hasil pengujian variabel diversitas kebangsaan $\left(\mathrm{X}_{2}\right)$, diperoleh nilai p-value sebesar $0,005 / 2=$ 0,0025 (uji satu sisi) lebih rendah dari $\alpha=0,05$ dengan nilai koefisien $\beta=0,066$. Angka-angka ini menjelaskan bahwa diversitas kebangsaan berpengaruh positif pada luas IC Disclosure, sehingga $\mathrm{H}_{2}$ diterima. Sedangkan variabel diversitas pengalaman $\left(X_{3}\right)$ memiliki nilai p-value sebesar 0,593/2 =0,2965 (uji satu sisi) lebih timggi dari $\alpha=0,05$ dengan nilai koefisien $\beta=0,001$. Hal tersebut menginformasikan bahwa diversitas pengalaman tidak berpengaruh pada luas $I C$ Disclosure, sehingga $\mathrm{H}_{3}$ tidak dapat diterima.

\section{Hasil Uji Nilai Selisih Mutlak}

Hasil pengujian hipotesis 4 hingga hipotesis 6 dengan menggunakan uji nilai selisih mutlak akan dijabarkan dalam Tabel 4 berikut ini.

Tabel 4.

\section{Hasil Uji Nilai Selisih Mutlak}

\begin{tabular}{ccccc}
\hline & Unstandardized & Standardized & & \\
Model & Coefficients & Coefficients & T & Prob. \\
\hline
\end{tabular}




\begin{tabular}{crrrrr}
\hline & \multicolumn{1}{c}{ B } & Std. Error & Beta & & \\
$\mathrm{C}$ & 0,430 & 0,008 & & 52,818 & 0,000 \\
$\mathrm{X}_{1}$ & $-0,009$ & 0,005 & $-0,244$ & $-2,005$ & 0,049 \\
$\mathrm{X}_{2}$ & 0,005 & 0,005 & 0,127 & 1,005 & 0,318 \\
$\mathrm{X}_{3}$ & 0,003 & 0,004 & 0,082 & 0,718 & 0,475 \\
$\mathrm{X}_{4}$ & $-0,003$ & 0,004 & $-0,076$ & $-0,647$ & 0,520 \\
$\left|\mathrm{X}_{1}-\mathrm{X}_{4}\right|^{*}$ & $-0,015$ & 0,007 & $-0,263$ & $-2,106$ & $* 0,039$ \\
$\left|\mathrm{X}_{2}-\mathrm{X}_{4}\right|^{*}$ & 0,021 & 0,008 & 0,365 & 2,607 & $* 0,011$ \\
$\left|\mathrm{X}_{3}-\mathrm{X}_{4}\right|$ & 0,001 & 0,004 & 0,028 & 0,244 & 0,808 \\
Uji F & & & 6,025 & & \\
Sig. F & & & 0,000 & & \\
Adjusted $R$ Square & & & 0,314 & &
\end{tabular}

Sumber : Data yang diolah, 2016

Keterangan : $*$ berpengaruh signifikan pada tingkat signifikansi $5 \%$

Berdasarkan Tabel 4 di atas dapat dirumuskan persamaan regresi sebagai berikut.

$$
\begin{aligned}
& \mathrm{Y}=0,430-0,009 \mathrm{X}_{1}+0,005 \mathrm{X}_{2}+0,003 \mathrm{X}_{3^{-}} 0,003 \mathrm{X}_{4}-0,015\left|\mathrm{X}_{1}-\mathrm{X}_{4}\right|+0,021\left|\mathrm{X}_{2}-\mathrm{X}_{4}\right|
\end{aligned}
$$

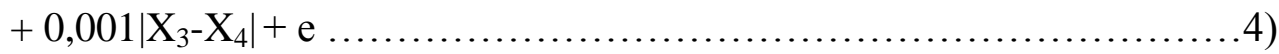

Tabel 4 menunjukkan nilai $F_{\text {hitung }}$ sebesar 6,025 dengan p-value sebesar 0,000 lebih rendah dari $\alpha=0,05$. Hal ini berarti semua variabel bebas dan moderasi secara simultan dan signifikan mampu menjelaskan perubahan variabel terikat, sehingga model penelitian dinyatakan layak (fit). Nilai Ajusted $R^{2}$ sebesar 0,314 menjelaskan bahwa 31,4 persen perubahan dari luas IC Disclosure dipengaruhi oleh diversitas gender, kebangsaan, dan pengalaman dewan, serta interaksi dari kepemilikan institusional dengan masing-masing variabel tersebut.

Tabel 4 juga menjelaskan bahwa nilai koefisien $\beta X_{1} \cdot X_{4}$ sebesar $-0,015$ dengan p-value sebesar 0,039 lebih rendah dari $\alpha=0,05$. Hal ini berarti kepemilikan institusional mampu memperkuat pengaruh (negatif) diversitas gender pada luas IC Disclosure, sehingga $\mathrm{H}_{4}$ diterima. Berdasar pada Tabel 4, dapat pula diinformasikan bahwa variabel $X_{1}$ dan variabel interaksi $X_{1} \cdot X_{4}$ memiliki nilai koefisien yang signifikan, sehingga kepemillikan institusional merupakan variabel moderasi semu (quasi moderation). 
I.A Ika Vedanti Pratiwi, I Dewa Nym Badera, dan I Kt Budiartha. Kemampuan...

Tabel 4 juga menunjukkan nilai $\beta \quad \mathrm{X}_{2} . \mathrm{X}_{4}$ sebesar 0,021 dengan $\mathrm{p}$-value sebesar 0.11 lebih rendah dari $\alpha=0,05$. Hal tersebut berarti kepemilikan institusional memperkuat pengaruh diversitas kebangsaan pada luas IC Disclosure, sehingga $\mathrm{H}_{5}$ diterima. Tabel 4 juga menginformasikan bahwa variabel $\mathrm{X}_{2}$ memiliki nilai koefisien regresi yang tidak signifikan, sedangkan variabel interaksi $\mathrm{X}_{2} \cdot \mathrm{X}_{4}$ menunjukkan nilai koefisien yang signifikan, pada kondisi ini kepemilikan institusional merupakan variabel moderasi murni (pure moderation).

Hasil uji hipotesis pada Tabel 4 menjelaskan bahwa hasil koefisien $\beta \mathrm{X}_{3}$. $\mathrm{X}_{4}$ sebesar 0,001 dengan p-value 0,808 lebih tinggi dari $\alpha=0,05$. Hal ini berarti kepemilikan institusional tidak mampu memoderasi pengaruh diversitas pengalaman pada luas IC Disclosure, sehingga $\mathrm{H}_{6}$ tidak dapat diterima. Tabel 4 juga menunjukkan bahwa variabel $\mathrm{X}_{3}$ dan variabel interaksi $\mathrm{X}_{3} \cdot \mathrm{X}_{4}$ memiliki nilai koefisien yang tidak signifikan. Hal ini menjelaskan bahwa kepemilikan institusional merupakan variabel moderasi potensial (homologizer variabel).

\section{Pengaruh Diversitas Gender Pada Luas Intellectual Capital Disclosure}

Pada umumnya keberadaan dewan direksi dan komisaris wanita diharapkan mampu membentuk kolaborasi yang baik ketika disandingkan dengan dewan direksi dan komisaris pria dalam proses pengambilan keputusan. Bahkan Krishnan dan Park (2005) berhasil membuktikan bahwa dewan wanita memberi pengaruh positif pada peningkatan kinerja perusahaan. Namun pada suatu taraf pencapaian kesuksesan tertentu, dewan direksi dan komisaris wanita kerap menunjukkan 
kehati-hatiannya dalam mengambil keputusan dan cenderung menjadi riks averse (Francis et al., 2014). Apabila sikap konservatif ini dikaitkan dengan proses pengambilan keputusan untuk mengungkapkan informasi modal intelektual, maka sikap tersebut cenderung akan menurunkan luas IC Disclosure, sebab informasi modal intelektual yang tersebar di pasar modal tidak hanya bermanfaat bagi para stakeholder untuk mengambil keputusan dan menilai prospek perusahaan, namun juga memudahkan pesaing untuk menganalisis peluang-peluang penciptaan nilai, yang justru berbalik merugikan perusahaan (Purnomosidhi, 2006).

Primo dkk (2003) menyebutkan bahwa peran wanita di dalam industri teknologi informasi belum dapat dirasakan secara signifikan, pernyataan tersebut diperkuat dengan hasil penelitian UNESCO yaitu secara umum pemimpin wanita untuk kawasan Asia-Pasific termasuk Indonesia belum dilatih untuk bergelut pada dunia teknologi informasi. Hal ini secara tidak langsung berdampak pada minimnya pengungkapan informasi modal intelektual yang mampu disajikan kepada publik. Sehingga dapat dikatakan bahwa diversitas gender berpengaruh negatif pada luas IC Disclosure. Hasil penelitian ini mendukung penelitian Francis et al (2014) dan Handajani et al (2014).

\section{Pengaruh Diversitas Kebangsaan Pada Luas Intellectual Capital Disclosure}

Rasmini et al (2014) mengungkapkan bahwa keberadaan dewan direksi dan komisaris berkebangsaan asing akan membawa iklim perubahan yang positif pada proses pengelolaan perusahaan, dimana dewan asing yang dibekali dengan kualitas memadai baik dari segi pengetahuan, tingkat profesionalitas, budaya organisasi, maupun perspektif yang beragam akan memberi berbagai alternatif 
I.A Ika Vedanti Pratiwi, I Dewa Nym Badera, dan I Kt Budiartha. Kemampuan...

strategi dan kebijakan, yang tentunya berdampak positif pada peningkatan kinerja perusahaan. Pada umumnya, perusahaan dengan kinerja mempuni akan memaksimalkan pengungkapan informasi guna memberi sinyal positif kepada publik tentang prospek perusahaan (Rasmini et al., 2014). Keberadaan dewan berkebangsaan asing menandakan bahwa perusahaan akan senantiasa memaksimalkan keterbukaan informasi yang diyakini sejalan dengan peningkatan luas pengungkapan sukarela, termasuk diantaranya IC Disclosure (Rasmini et al., 2014). Oleh sebab itu diversitas kebangsaan berpengaruh positif pada luas $I C$ Disclosure. Hasil penelitian ini mendukung penelitian Rasmini et al (2014) dan Oba et al (2013).

\section{Pengaruh Diversitas Pengalaman Pada Luas Intellectual Capital Disclosure}

Beragamnya pengalaman dewan direksi dan komisaris, khususnya pengalaman kerja selama memimpin perusahaan menjadi salah satu modal dalam mendukung proses pengelolaan perusahaan. Hal ini karena pengalaman kerja yang mempuni menggambarkan adanya penambahan pengetahuan yang pada akhirnya mampu menggiring kinerja menjadi lebih baik. Menurut Sulaeman (2014) untuk mengukur pengalaman kerja dapat menggunakan indikator berupa masa jabatan. Masa jabatan yang panjang mampu membentuk seorang dewan menjadi lebih efektif, memiliki pengalaman kerja yang beragam, dan pengetahuan yang cukup tentang kebijakan maupun strategi yang tepat diaplikasikan dalam perusahaan.

Namun Finkelstein dan Hambrick (1990) menjelaskan bahwa pada saat seorang pemimpin telah mencapai taraf keberhasilan dengan berbekal pengalaman kerja mempuni selama menduduki masa jabatan, cenderung akan 
mempertahankan status quo dengan tetap menggunakan strategi lama di dalam mengelola perusahaan. Pada konteks ini dewan merasa bertahan di zona nyaman dengan strategi-strategi lama sudah cukup menghantarkan perusahaan pada kinerja yang baik, sehingga membuatnya enggan untuk mengadopsi strategistrategi berbeda yang belum pernah diterapkan sebelumnya (Katz, 1982), seperti contohnya mencoba untuk memaksimalkan pengaplikasian modal intelektual, kemudian mengungkapkan informasi tersebut kepada publik. Hasil penelitian ini mendukung penelitian Soheilyfar et al (2014).

\section{Pengaruh Diversitas Gender Pada Luas Intellectual Capital Disclosure dengan Kepemilikan Institusional Sebagai Variabel Moderasi}

Smith (1996) menekankan bahwa pada umumnya keberadaan investor institusi dalam perusahaan diharapkan dapat berperan sebagai agen pengawas yang bertugas untuk memastikan bahwa perusahaan telah dikelola secara baik sesuai standar yang berlaku. Namun ketika dihadapkan pada strategi persaingan bisnis, interaksi yang terbentuk antara dewan wanita dan investor institusional disinyalir dapat mengurangi luas IC Disclosure, sebab investor institusi dengan kepemilikan saham yang tinggi cenderung akan melindungi sejumlah besar investasinya dengan mendukung keputusan dewan wanita dalam meminimaliasi IC Disclosure guna menghindari competitive disadvantage. Singkat kata, ketika para pesaing memanfaatkan informasi modal intelektual untuk kepentingannya, maka informasi tersebut akan berbalik merugikan perusahaan (Purnomosidhi, 2006). Hasil penelitian ini mendukung Nurziah dan Darmawati (2014) yaitu 
I.A Ika Vedanti Pratiwi, I Dewa Nym Badera, dan I Kt Budiartha. Kemampuan...

semakin tinggi kepemilikan saham institusi, maka akan mengurangi luas pengungkapan sukarela yang dilakukan perusahaan.

\section{Pengaruh Diversitas Kebangsaan Pada Luas Intellectual Capital Disclosure dengan Kepemilikan Institusional Sebagai Variabel Moderasi}

Interaksi yang terjalin diantara investor institusi dengan dewan berkebangsaan asing diyakini akan meningkatkan luas IC Disclosure, sebab pengungkapan informasi modal intelektual merupakan berita baik bagi investor karena menggambarkan keunggulan kompetitif perusahaan, sehingga berpotensi untuk meningkatkan nilai perusahaan di masa mendatang (Devi, 2016). Peningkatan nilai perusahaan sejalan dengan besarnya cashflow yang mampu diterima oleh perusahaan tersebut, dan tingginya kepemilikan saham berbanding lurus dengan cashflow yang akan didapatkan oleh pemegang saham, yang mana apabila nilai perusahaan meningkat, maka investor institusi sebagai pemegang saham mayoritas yang paling banyak merasakan manfaatnya (Nuryaman, 2009). Berdasarkan hal tersebut dapat dijelasan bahwa pengungkapan informasi modal intelektual yang memadai berpotensi untuk meningkatkan kesejahteraan investor institusi, sehingga investor tersebut cenderung mendukung keputusan dewan asing untuk meningkatkan keterbukaan informasi modal intelektual bahkan hingga ke ranah internasional. Hasil penelitian ini mendukung penelitian Mahmudi dan Rostami (2014).

Pengaruh Diversitas Pengalaman Pada Luas Intellectual Capital Disclosure dengan Kepemilikan Institusional Sebagai Variabel Moderasi 
Pada umumnya, pengalaman kerja yang diperoleh selama masa jabatan membuat seorang pemimpin perusahaan mampu membentuk reputasi yang baik dimata stakeholder bahwa dirinya akan mengelola dan mengawasi perusahaan dengan baik, dan senantiasa memenuhi kebutuhan seluruh pihak yang berkepentingan atas perusahaan tanpa terkecuali Menurut Aini dan Sumiyana (2008), reputasi pimpinan puncak merupakan persepsi yang dihasilkan dari akumulasi keahlian, pengalaman, dan hubungan sosial yang mampu dibentuk seorang pemimpin perusahaan dengan lingkungannya. Reputasi yang telah berhasil dimiliki dewan dengan pengalaman kerja mempuni secara tidak langsung akan melahirkan kepercayaan pemegang saham institusi bahwa perusahaan telah dikelola berdasarkan prinsip-prinsip GCG, termasuk dari segi keterbukaan informasi (Aini \& Sumiyana, 2008). Kepercayaan ini pada akhirnya akan mengurangi motivasi pemegang saham untuk mengawasi pengelolaan perusahaan (Jones, 2014). Oleh sebab itu, keberadaan investor institusional tidak mampu memoderasi pengaruh diversitas pengalaman, khususnya pengalaman kerja dewan direksi dan komisaris pada luas IC Disclosure. Hasil penelitian ini mendukung penelitian Yunita (2012).

\section{SIMPULAN DAN SARAN}

Kesimpulan penelitian ialah Diversitas gender dari dewan direksi dan komisaris berpengaruh negatif pada luas Intellectual Capital Disclosure. Diversitas kebangsaan dari dewan direksi dan komisaris berpengaruh positif pada luas Intellectual Capital Disclosure. Diversitas pengalaman dari dewan direksi dan komisaris tidak berpengaruh pada luas Intellectual Capital Disclosure. 
I.A Ika Vedanti Pratiwi, I Dewa Nym Badera, dan I Kt Budiartha. Kemampuan...

Kepemilikan institusional mampu memoderasi pengaruh diversitas gender dari dewan direksi dan komisaris pada luas Intellectual Capital Disclosure. Kepemilikan institusional mampu memoderasi pengaruh diversitas kebangsaan dari dewan direksi dan komisaris pada luas Intellectual Capital Disclosure. Kepemilikan institusional tidak mampu memoderasi pengaruh diversitas pengalaman dari dewan direksi dan komisaris pada luas Intellectual Capital Disclosure.

Keterbatasan penelitian ialah jenis diversitas yang digunakan hanya terbatas pada diversitas gender, kebangsaan, dan pengalaman dewan direksi dan komisaris. Hal ini dapat diamati dari nilai Adjusted $R$ Square hanya sebesar 31,4 \%, yang menunjukkan bahwa varian dari variabel bebas dan interaksinya dengan variabel moderasi mampu menjelaskan variabel terikat sebanyak 31,4\%. Sedangkan 68,6\% dipengaruhi oleh variabel lain yang tidak dibahas dalam model. Keterbatasan lainnya ialah ruang lingkup diversitas pengalaman, hanya berfokus pada pengalaman kerja dewan direksi dan komisaris di satu perusahaan.

Berdasarkan keterbatasan tersebut, maka saran yang dapat diajukan ialah: Peneliti selanjutnya dapat mempertimbangkan jenis diversitas lain sebagai variabel independen yang dinilai mampu mempengaruhi luas IC Disclosure, seperti diversitas usia, etnis, dan latar belakang pendidikan. Peneliti berikutnya dapat memperluas ruang lingkup diversitas pengalaman, misalnya pengalaman dewan selama bekerja di perusahaan lain yang tentu saja berperan dalam menambah keterampilan dan pengetahuan dewan. Penelitian ini hanya menggunakan periode amatan selama 4 tahun. Peneliti selanjutnya dapat 
memperpanjang periode amatan agar dapat menilai konsitensi hasil penelitian, sebab setiap perusahaan berpotensi mengembangkan luas pengungkapan informasi sukarela sesuai dengan kebutuhannya.

\section{REFERENSI}

Abdiani, Dinis dan Yeterina Widi Nugrahanti. 2014. Perbedaan Pengungkapan Intellectual Capital Berdasarkan Tipe Industri dan Perbedaan Kapitalisasi Pasar Berdasarkan Pengungkapan Intellectual Capital. Jurnal Cakrawala Akuntansi, 6 (2): $110-125$.

Aini, Rias dan Sumiyana. 2008. Pengaruh Reputasi Manajemen Puncak dan Dewan Komisaris Terhadap Penilaian Investor Pada Perusahaan Yang Melakukan IPO. Jurnal Akuntansi dan Keuangan Indonesia, 5 (2): 202-226.

Baroko, G Dulacha dan Brown Alistair M. 2008. Corporate Social Reporting and Board Representation Evidence From Kenyan Banking Sector. Journal of Management and Governance, 12 (4): 309-324.

Baroroh, Niswah. 2013. Analisis Pengaruh Modal Intelektual Terhadap Kinerja Keuangan Perusahaan Manufaktur di Indonesia. Jurnal Dinamika Akuntansi, 5 (2): 172-182.

CIMA. 2004. Undestanding Corporate Value: Managing and Reporting Intellectual Capital. Britania Raya: Chartered Institute of Management Accountants.

Devi, Sunitha. 2016. Pengaruh Enterprise Risk Management Disclosure dan Intellectual Capital Disclosure Pada Nilai Perusahaan. E-Jurnal Ekonomi dan Bisnis Unud, 3 (10): 1-36.

Dewan Standar Akuntansi Keuangan. 2015. Standar Akuntansi Keuangan. Jakarta: Dewan Standar Akuntansi Keuangan Ikatan Akuntan Indonesia.

Febriana, Dwiga Ayuning dan Yeterina Widi Nugrahanti. 2013. Analisis Perbedaan Pengungkapan Intellectual Capital Berdasarkan Struktur Kepemilikan (Studi Pada Perusahaan Manufaktur Yang Terdaftar di BEI 2011). JP FEB Unsoed Journal dan Proceeding, 3 (1): 1-13.

Finkelstein, S, dan D. Hambrick. 1990. Top Management Team Tenure and Organizational Outcomes: The Moderating Role of Managerial Discretion. Administrative Science Quarterly, 35 (3): 484-503. 
I.A Ika Vedanti Pratiwi, I Dewa Nym Badera, dan I Kt Budiartha. Kemampuan...

Foerthiono, Arlin Novyenly dan Sadjiarto. R. Arja. 2014. Faktor-Faktor yang Mempengaruhi Minat Mahasiswa Akuntansi Berkarier Sebagai Akuntan Publik dengan Persepsi Etis Skandal Akuntansi Sebagai Variabel Intervening. Tax \& Accounting Review, 4 (2): 1-7.

Francis, Bill, Iftekar Hasan, Jong Chool Park, Qiang Wu. 2014. Gender. Differences ini Financial Reporting Decision-Making: Evidence From Accounting Conservatism. Bank of Finland Research Discussion Papers 1. pp: 2-61.

Ghozali, Imam. 2016. Aplikasi Analisis Multivariate dengan Program IBM SPSS 23. Semarang: Badan Penerbit Universitas Diponegoro.

Gouiaa, Raef, dan Daniel Zeghal. 2015. Analysis of The Effect of Corporate Governance Attributes and Disclosure Level on Firm's Costs of Financing. Journal of Modern Accounting and Auditing, 11 (11): 561-580.

Handajani, Lilik, Bambang Subroto, Sutrisno T, dan Erwin Saraswati. 2014. Does Board Diversity Matter on Corporate Social Disclosure? An Evidence. Journal of Economics and Suistanable Development, 5 (9): 8-16.

Herwidayatmo. 2002. Siaran Pers Badan Pengawas Pasar Modal Tanggal 27 Desember. http://www.hitpages.com (diunduh tanggal 31 Juni 2016).

Intruksi Presiden Republik Indonesia Nomor 9 Tahun 2000 Tentang Pengarustamaan Gender dalam Pembangunan Nasional. Jakarta.

Jensen, Michael C dan William. H Meckling. 1976. Theory of The Firm: Managerial Behavior, Agency Costs and Ownership Structure. Journal of Financial Economics, 3 (4): 305-360.

Jones, Gregory Todd. 2014. Trust, Institutionalization \& Corporate Reputations: Public Independent Fact-Finding From A Risk Management Perpective. University of Miami Business Law Review: 13 (2): 121-160.

Kahle, Murren I Muller dan Krista B. Lewellyn. 2011. Did Board Configuration Matter? The Case Of US Subprime Lenders. Corporate Governance: An International Review, 19 (5): 405-417.

Kartikarini, Nurrahmah dan Siti Mutmainah. 2013. Analisis Pengaruh Diversitas Gender Terhadap Voluntary Corporate Governance Disclosure Dalam Laporan Tahunan Perusahaan. Diponegoro Journal of Accounting, 2 (1): 1-15.

Katz, Ralph. 1982. The Effects of Group Longevity on Project Communication and Peformance. Administrative Science Quaterly, 27 (1): 81-104. 
Kompas. 2016. Luhut: Tak Masuk Akal Kalau Tenaga Kerja Asing China Ada 10 Juta Orang. http://www.nasional.kompas.com (diunduh tanggal 20 Juli 2016).

Krishnan, Hema A dan Daewoo Park. 2005. A Few Good Women-On Top Management Teams. Journal of Business Research, 58 (12): 1712-1720.

Li, Huimin, Harley E. Ryan Jr, Lingling Wang, Baozhong Yang. 2013. Family Firms and Boards of Directors: Evidence From Board Tenure. ISB Insight, pp: 126.

Mahmudi dan Rostami. 2014. The Relationship Between Ownership Structure and Voluntary Disclosure Among Listed Companies on The Tehran Stock Exchange. Asian Research Consortium, 4 (10): 87-109.

Nuryaman. 2009. Pengaruh Konsentrasi Kepemilikan, Ukuran Perusahaan, dan Mekanisme Corporate Governance Terhadap Pengungkapan Sukarela. Jurnal Akuntansi dan Keuangan Indonesia. 6 (1): 89-116.

Oba, Victor Chiedu, Jide IBIKUNLE, Yau Mohammed DAMAGUM. 2013. The Impact of Board Mechanisms on Intellectual Capital Disclosures in Nigeria. Journal of Accounting and Management, 3 (1): 65-80.

Oyieke, O. Samuel. 2014. Firm's Financial Performance and Corporate Board Diversity: Evidence From Kenya. (African Ecomics Research Consortium). Jaramogi Oginga Ondinga University, Kenya.

Permanasari, Meiryananda. 2012. Pengaruh Karakerteristik Perusahaan dan Mekanisme Corporate Governance Terhadap Pengungkapan Informasi. Jurnal Bisnis dan Akuntansi, 4 (3): 193-212.

Poerwati, Tjahjaning. 2001. Pengaruh Partisipasi Penyusunan Anggaran Terhadap Kinerja Manajerial: Budaya Organisasi dan Motivasi Sebagai Variabel Pemoderasi. Tesis. Program Studi Magister Akuntansi, Universitas Diponegoro.

Pratiwi, Irna. 2013. Faktor-Faktor Penentu Asas Pengungkapan Modal Intelektual di Indonesia. Skripsi. Fakultas Ekonomi, Universitas Indonesia.

Primo, Natasha. 2013. Gender Issues In The Information Society. Paris: United Nations Educational, Scientific and Cultural Organization (UNESCO).

Purnomosidhi, Bambang. 2006. Praktik Pengungkapan Modal Intelektual Pada Perusahaan Publik di BEJ. Jurnal Riset Akuntansi Indonesia, 9 (1): 1-25.

Purwanto, Eko dan Ira Wikartika. 2014. Analisis Voluntary Disclosure Perusahaan Telekomunikasi di BEI. Jurnal Neo-Bis, 8 (2): 1-15. 
I.A Ika Vedanti Pratiwi, I Dewa Nym Badera, dan I Kt Budiartha. Kemampuan...

Rahindayati, Ni Made, I Wayan Ramantha, Ni Ketut Rasmini. 2015. Pengaruh Diversitas Pengurus Pada Luas Pengungkapan Corporate Social Responsibility Perusahaan Sektor Keuangan. E-Jurnal Ekonomi dan Bisnis Universitas Udayana, 4 (5): 312-330.

Rasmini, Ni Ketut, Made Gede Wirakusuma, dan Ni Wayan Yuniasih. 2014. The Effect of Board Diversity on The Extent of Intellectual Capital Disclosure (Empirical Study In Indonesian Stocks Exchange). Asia Pasific Journal of Accounting and Finance, 3 (1): 46-58.

Robbins, Stephen P dan Timothy A. Judge. 2008. Perilaku Organisasi. Edisi 12. Jakarta: Salemba Empat.

Sartawi, Iaad. I. S. Mustafa, Riyad M. Hindawi, Ruba Bsoul, dan Ala'eddin Jamil Ali. 2014. Board Composition, Firm Characteristics, and Voluntary Disclosure: The Case of Jordanian Firm Listed on Amman Stock Exchange. International Business Research, 7 (6): 67-82.

Sir, Jennie, Bambang Subroto, dan Grahita Chandrarin. 2010. Intellectual Capital dan Abnormal Return Saham. Siposium Nasional XIII Purwekerto 2010. Hal 1-27.

Smith. Michael. P. 1996. Shareholder Activism by Institusional Investors: Evidenve From CalPERS. The Journal of Finance, 51 (1): 227-252.

Soheilyfar, Fatemeh, Mohammad Tamimi, Mohammad Ramezan Ahmadi, dan Nasrollah Takhtaei. 2014. Disclosure Quality and Corporate Governance: Evidence From Iran. Asian Journal of Finance \& Accounting, 6 (2): 75-85.

Sulaeman, Ardika. 2014. Pengaruh Upah dan Pengalaman Kerja Terhadap Produktivitas Karyawan Kerajinan Ukiran Kabupaten Subang. Trikonomika, 13 (1): 91-100.

Widodo, Nova Maulud dan Ari Kuncara Widagdo. 2015. Struktur Kepemilikan Terhadap Pengungkapan Akuntansi Sumber Daya Manusia. JP Journal \& Proceeding, 5 (1): 1-11.

Williams, Katherine Y dan Charles A. O' Reilly. 1998. Demography and Diversity In Organizations: A Review of 40 Years of Research. Research In Organizational Behavior, Vol. 20: 77-140.

Winato Pauline Jayalaksmi dan Supatmi. 2016. Pengaruh Kebangsaan Board Directors Pada Nilai Perusahaan. Seminar Nasional Riset Manajemen dan Bisnis 2016, pp: 1-10.

Yunita, Nancy. 2012. Pengaruh Corporate Governance Terhadap Voluntary Disclosure dan Biaya Hutang. Jurnal Ilmiah Mahasiswa Akuntansi, 1 (1): 90-96. 